Disponível em:

http://editora.unoesc.edu.br/index.php/race

Race, Joaçaba, v. 15, n. 2, p. 729-750, maio/ago. 2016

\title{
THE MARKET PROSPECTS OF COLONIAL PRODUCTS ${ }^{1}$
}

\author{
As perspectivas de mercado do produto colonial
}

Larissa Schaefer

E-mail: schaefer.lari@gmail.com

Bachelor in Business Administration with emphasis on foreign trade by Universidade do Oeste de Santa Catarina.

Silvio Santos Junior

E-mail: silviosantos.junior@unoesc.edu.br

Doctor in Agribusiness and Master in Business Administration by Universidade Federal do Rio Grande do Sul; Professor and researcher at Master's Degree Program in Administration by Universidade do Oeste de Santa Catarina. Contact address: Rua Getúlio Vargas, 2125, Flor da Serra, 89600-000, Joaçaba, Santa Catarina, Brasil.

Article received on April 13 ${ }^{\text {th }}$ 2016. Accepted on April 25 2016. 
Abstract

With the competitiveness increasing in the Brazilian agribusinesses, studies related to the survival of small farms encourage the strategy of agro-industrialization, but warn about the possibility of adulteration of the primary attributes: the traditional way of making the products. In this context, the aim of this study is to identify the importance given by the consumer to "colonial appeal" and the reasons that influence the choice for this type of product. This is a research survey, conducted with 300 families in the city of Chapecó, SC. The results show that the colonial product has a distinctive call, and that the perceptions of importance vary according to the age, confirming the findings of previous studies.

Keywords: Agricultural markets. Colonial product. Consumption.

\section{Resumo}

Com a crescente competitividade no agronegócio brasileiro, estudos relacionados a sobrevivência da pequena propriedade rural estimulam a estratégia de agroindustrialização, mas alertam para a possibilidade de descaracterização de seus atributos primordiais: a forma artesanal de fazer os produtos. Neste contexto, o objetivo deste estudo é identificar a importância dada pelo consumidor ao "apelo colonial" e os motivos que influenciam a escolha por este tipo de produto. Trata-se de uma pesquisa survey, realizada com 300 famílias da cidade de Chapecó, SC. Os resultados mostram que o produto colonial tem um apelo diferenciador, e que as percepções de importância variam em função da idade, confirmando achados de estudos anteriores.

Palavras-chave: Mercados agrícolas. Produto colonial. Consumo.

\section{INTRODUCTION}

Agribusinesses in level Brazil has been the scene of several studies related to the future prospects of the colonial product ${ }^{2}$ and rural development (MIOR, 2003; DORIGON, 2008; SANTOS JUNIOR, 2011). Studies show that, faced by increasing competition imposed by the modernization of the countryside, the small farmers compete in an unfavorable environment for survival. To mitigate the effects of public policy scenarios to encourage small farmers have been implemented. Special attention is given to PRONAF, ${ }^{3}$ which through a subprogram, regulated by Law 11.947-2009, in Clause n. 14 brought changes to the National Program of Academic Feeding, leaving aside the logic of the lowest price to the buying public, and encourage family farming and local development (REINACH; CORÁ; BONDUKI, 2012).

Other public politics have encouraged the creation of small rural agro-industries (RAs) to promote rural development (BANCO REGIONAL DE DESENVOL- 
VIMENTO DO EXTREMO SUL, 2004; PEREIRA; NEVES; CASAROTTO FILHO, 2004; KALNIN, 2004). However, the Brazilian law to agribusinesses, created in the last century aimed at large enterprises, contains institutional requirements that make it often impractical for small farmers (GUIMARÃES, 2001), and inducing the disfigure risk in main attribute: craft production in small scale, with recognized marketing appeal (DORIGON, 2008; SANTOS JUNIOR; WAQUIL, 2012).

This “colonial appeal” is defended in several studies on rural development, as a competitive advantage of smaller RAs. It appears, however, that to suit the standards and processes required by the institutional environment, RAs tend to standardize their processes so that they can enter the market (WILKINSON, 2008). This process of standardization, in turn, makes room for the large agribusinesses to appropriate "colonial appeal”, adding to their customer scope those who have this preference (RENARD, 2003; WILKINSON, 2003). In this context, Santos Junior (2011, p. 143) argues that:

[...] the formalization required by the formal institutional environment [...] appears to induce the RAs to produce within the conventional fitting, then pay attention to the warnings of Wilkinson and Renard, that these RAs do not decharacterizes their products (colonial) and consequently lose market niches for large agribusinesses. In this sense this institutional factor appears to be in a long-term threat to the RAs seeking standardization (and conventional quality productmatch) and a short-term threat to those who are less concerned with standardization.

For Wilkinson and Mior (1999):

[...] market regulation constitutes an ideal area for definition of interests among various actors, both in production and consumption. Trading around the rules and industry standards does not translate to neutral criteria of efficiency and/or public interests of health and hygiene. Above all, it is a negotiation key, first, on what should be included in the market and, secondly, about the values that should regulate these markets, particularly concerning the types of producers and consumers that should be included. (MIOR; WILKINSON, 1999, p. 44).

Several other authors (BENEDET FILHO, 2004; SANTOS, 2006; FIGUEIREDO, 2003; KIYOTA, 1999; PREZOTTO, 1999; MEDEIROS; WILKINSON; LIMA, 2002; MIOR, 2003) argue that the standardization required to RAs by the 
institutions, implies a competition for which they do not have the power or not it suits them, or do not wish to participate.

This study was aimed to investigate the importance that the "colonial appeal” has for consumers and, consequently, the impact on the competitiveness of small and medium-sized enterprises. The study has as research objects the final consumer, and is bounded in the city of Chapecó, SC. It is therefore a descriptive study that will seek to confirm (or not) the findings of previous studies.

In addition to this introductory section, this article presents the second section, the theoretical foundation, contextualizing the locus of the study, rescuing elements of sectoral legislation, as well as on the theory of consumption, which will support the study. The third section presents the methodology, procedures and techniques applied in this study. The fourth section presents the results of the study and a comparative analysis with previous research findings. The fifth section presents the conclusions and suggestions for future studies.

\section{CONTEXT OF THE STUDY}

Since the colonial period (1500-1822) to the Old Republic (1889-1930) the Brazilian economy depended on the good performance of exports, which during this period were limited to some agricultural commodities. This feature although less degree, is still present in the current context, and features the country as an agro-export economy (GREMAUD, 2007). In the current context, the Ministry of Industry and Foreign Trade Development (MDIC) (2012), Brazilian agribusiness has strongly contributed to the generation of foreign exchange of the country between 2000 and 2011, the export volume grew by almost 155\% and external prices, 131\%. Among the main products exported by agribusiness are: soybeans, soybean oil, soybean meal, chicken, orange juice, coffee, pork, sugar, beef and fruits.

The southern region of Brazil, using the know-how inherited from the colonial era (MIOR, 2005), it is a traditional producer of pork derivatives, cheeses, jams, jellies, vegetable preserves, pasta, biscuits, brown sugar, wine, juice grape, among others. These products, when made by hand, are called "colonial products" and are produced in small RAs. For these small agribusinesses step into the formal market, are several intervening factors. Among others, it is required the attendance of institutional conditions to standardization ensure of structures and processes (GUIMARÃES; SILVEIRA, 2007), to ensure food safety. It happens, however, that in seeking to conform to the standards and procedures required by the institutional environment increasingly 
tend to standardize, being big challenge to keep those distinguishing characteristics (WILKINSON, 2008), featuring handcrafted products.

Santa Catarina, especially the West of Santa Catarina, locus of this study, has a peculiar historical and chronological context for the establishment and development of these RAs. According to Santos Junior (2011, p. 28):

In West of Santa Catarina, Mior (2003) demonstrates the changing dynamics that have occurred in the region. By one hand the vertical industrialization of meat, carried out by conventional large agribusinesses, to the 90 years promoted the inclusion of a large number of small farmers, and from that decade, due to the internationalization strategies and the result of required specialization by the economic opening of Brazil, to the exclusion of less competitive. On the other hand, these large corporations would provide an environment for the formation of a cluster that also benefits the other located there RAs, providing opportunity conditions of those excluded (and other smaller entrepreneurs) occupy the spaces of markets left by these large agribusinesses.

In this line of reasoning, the managers of the state of Santa Catarina have been guiding their public politics for rural areas favoring activities that add value to primary production, of which the RAs constitute one of the priority alternatives.

Next is a background brief of agribusiness in the state, with an emphasis on West Santa Catarina.

\subsection{THE PRODUCTIVE DIVERSIFICATION OF SANTA CATARINA}

The state of Santa Catarina has a diversified productive structure due to the natural resources, forms of territorial occupation, colonization and its historical evolution. The state occupies about $1 \%$ of the national territory, considered small, and was the tenth largest exporter, with a share of 3.53\% of Brazilian exports in 2010 (SANTA CATARINA, 2011). Each region is specialized and productive in a particular industry. To illustrate each region of the state and their industrial centers can be seen on the map 1 the state of division in six mesoregions. 


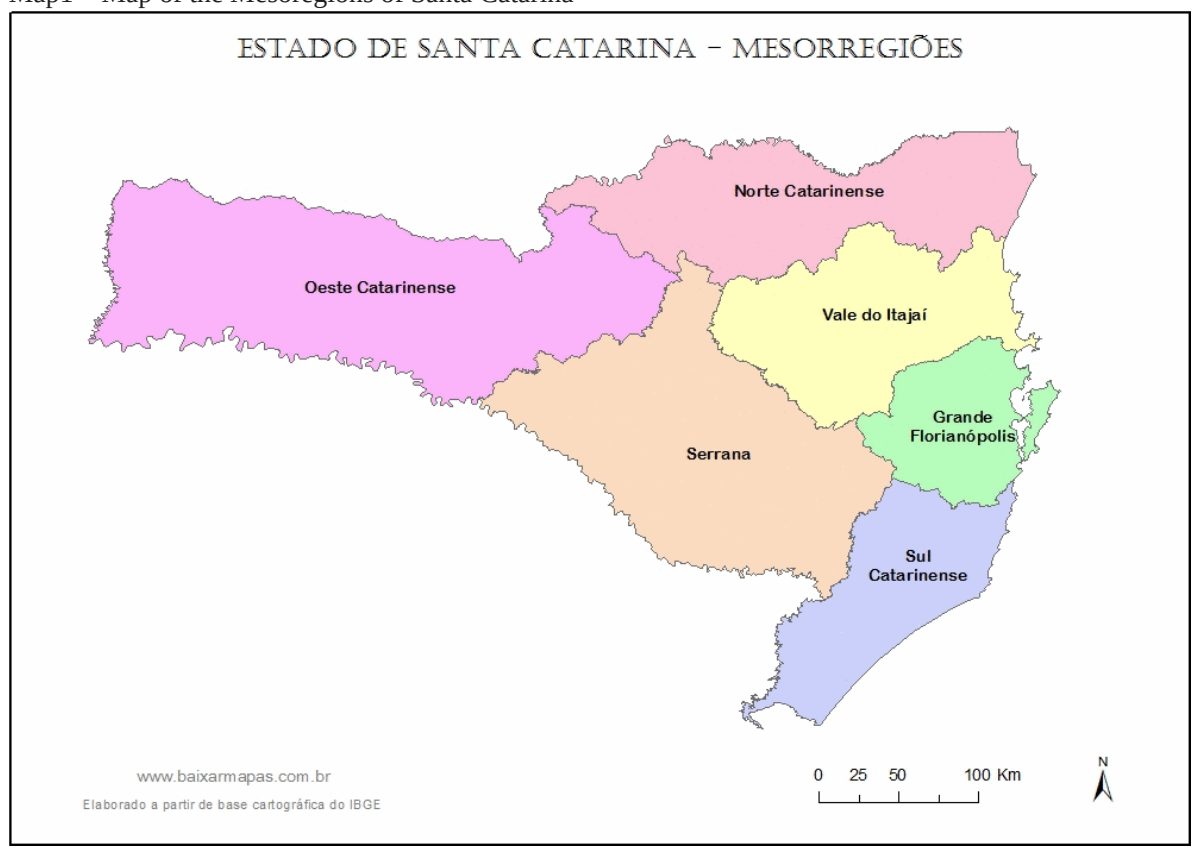

Source: Baixar mapas (2016).

The region called Greater Florianópolis, to the east, has their economic foundation in the technology industry; the North region of Santa Catarina is characterized by the manufacturing industry, metalworking, chemical trade, and plastic; in the West region of Santa Catarina (locus of this study), there is a strong presence of the food industry, especially in the poultry and swine industry; in the Mountainous region, it is centered the presence of cellulose and ceramics industries; in the Southern region of Santa Catarina, there is a predominance of coal mining industry as well as agriculture; and finally the Itajaí Valley region, is a textile hub and has port area in Itajaí. Despite the heterogeneity of economic scenarios, two sectors occupy about $60 \%$ of Santa Catarina's industrial transformation: Electro-metal-mechanical industry and the food industry (MIOR, 2005).

Consequently, Santa Catarina is national prominence by being the first producer of pork, apple, garlic and honey, the second largest poultry producer, and have strong representation in the production of milk, corn, beans, onions, rice and tobacco. The vast majority of these products are consumed internally in the country and/or exported, showing the exporting feature state (MIOR, 2005). 


\subsubsection{The context of the study in the West of Santa Catarina}

The production concentration in the western region of Santa Catarina is predominantly agricultural and agro-industrial, and from this production the state absorbs only a small percentage, highlighting the dependence of consumption on the domestic and foreign markets on the global economic dynamics. Thus, the integration of the regional market to foreign markets make the region an interesting setting for interrelations studies between global trends and local adaptation alternatives (MIOR, 2005).

The emergence of the first agribusinesses in the region is the result of agricultural activities and the expansion of productive and industrial sector of the country. Farmers were encouraged to adopt new production strategies as the advancement of production technologies have evolved. Regional agribusinesses opted for an integrated system of governance, in which the farmer receives the input and technical and technological assistance, which is charged on the animals sale. Thus agribusiness guarantee the standardization and purchase and producer sales (BAVARESCO, 2005). The system integration began with the Sadia Group in 1950 and has expanded to other refrigerators systems, and, from 1970 to 1975, 95\% of slaughtered chickens were from integration systems (INSTITUTO CEPA, 2000).

Thus, to the 90 years the system has promoted the inclusion of a large number of small farmers, and from that decade, due to the internationalization strategies and the consequent specialization required by the economic opening of Brazil, to the exclusion of less competitive. The gravity of the situation is illustrated by the number of producers in an exclusion situation of the activity in the west of the state of Santa Catarina. According to Testa et al. (1996), only 36\% of farms could be considered viable. Another 36\% were in open undercapitalization and the remaining $28 \%$ were in subsistence or exclusion. They are, by one hand, against oligopolies suppliers of inputs and capital goods required for the production process and, secondly, against oligopolies, when negotiating the sale of their production. ${ }^{4}$ That is, individually, with low bargaining power, either with suppliers or with your customers. So its competitiveness has just restricted to productive efficiency, in which the small-scale production is presented as another difficulty.

RAs have been seen as one of the possibilities to solve the problem and the possibility of generating employment and income of small farmers setting in rural areas, they have been encouraged by various institutions. For the Regional Bank Far South Development (BRDE) (PEREIRA; NEVES; CASAROTTO FILHO, 2004), 
“[...] the small agribusinesses are beginning to be seen as territorial and regional development strategy to create job opportunities and income, which contributes to improving the quality of life of farmers and their attachment to the field.” Corroborating this expectation, other government funding agent out "[...] special attention to sectoral clusters of companies, cooperation or developed economic configuration, create competitive advantages for firms located there.” (BANCO NACIONAL DO DESENVOLVIMENTO, 2004). And “[...] despite the lack of official statistical data to perform more accurate analysis of the situation of small agribusinesses in terms of sustainability and growth, it is clear the role they play in economic and social life of the country, and especially Santa Catarina.” (PEREIRA; NEVES; CASAROTTO FILHO, 2004).

To actualize in the formal market RAs must meet the legal aspects, which is the next subsection.

\subsection{LEGISLATION AND MARKET RAS}

The coverage levels of Brazilian legislation on the production and sale of craft products, especially perishable limit their distribution in the domestic market. Brazilian law, created in the middle of the last century, was intended to benefit large enterprises, despising the large amount of small agro-industries as economic feasibility of alternative Guimarães (2001).

Changes with regional criterial, created a municipal legislation (SIM - Municipal Inspection System) and a state (SIS - State Inspection System) that allow circumventing certain criteria of federal regulation (SIF - Federal Inspection System). Still, when certain products begin to be known, and intend may marketing reach, come up against the SIS requirements. In an attempt to circumvent this problem in 2006 it was adopted a unique system of sanitary inspection (Suasa - Unified System for the Agricultural Health), which provides conditions for the trade of handicrafts in the country (WILKINSON, 2008). Their use, however, is still limited. "The subject is relevant, but of enormous lack of understanding, knowledge and administrative and technical qualifications by the Municipalities.” (MINISTÉRIO DO DESENVOLVIMENTO AGRÁRIO, MINISTÉRIO DA AGRICULTURA, PECUÁRIA E ABASTECIMENTO, 2014). ${ }^{5}$

The predominance of family agriculture has reinforced the importance of local markets and the government has become essential in the regulation of the sector (through SIM) in promoting trade and access to institutional markets, especially 
school meals (WILKINSON, 2009). The law 11.947-2009 in its Clause 14 brought changes to the National Program of Academic Feeding leaving aside the logic of the lowest price to the buying public, and promotes family farming and local development (REINACH; CORÁ; BONDUKI, 2012). “[...] The National Program of Academic Feeding creates mechanisms for the strengthening of family farmers, the formation of healthy eating habits and local development through public procurement" (REINACH; CORÁ; BONDUKI, 2012, p. 8) thus enabling relevant institutional market for RAs in the region.

\subsection{PROCESS OF THE CONSUMER PURCHASE DECISION}

Know and understand consumer behavior, based on the literature, provides theoretical support for data collection and information gathering to analyze the results, and understanding of the size of each variable.

Consumer choice of process depends on your needs and wants, informed the intrinsic and extrinsic influences, and should be considered that consumers can choose certain desire but choose something totally different (COBRA, 2003).

The behavior of people is based on various influences, and each interferes in a given process of choosing products and services differently and to varying degrees. People are influenced by the world around them and are under pressure from all sorts of factors, which ultimately intervene in their behavior (WELLS, 1978).

Barbosa and Campbell (2006) state that the consumption practices are, in themselves, an important sociological fact.

It indicates not only an analytical category, but also a "native
category" [perception of consumers], which classifies and or-
ganizes the world around us. [...] Thus, consumption involves
other forms of provision that not only those designed in the
traditional format purchase and sale of goods in market condi-
tions. (BARBOSA; CAMPBELL, 2006, p. 24-26).

Marketing, Kotler and Keller (2006) argue that the consumer goes through five stages during the purchase process, "[...] recognition of the problem, information search, and evaluation of alternatives, purchase decision and post-purchase behavior.” Depending on the product that will buy, it may skip or reverse some of the steps.

When a person decides to buy his usual colonial cheese, it jumps straight to the need for cheese in the buying decision, thus eliminating the search for information and evaluating alternatives. However, knowledge of these five steps provides an 
analysis of the full range of considerations that can arise when a consumer is faced with a new purchase (KOTLER; KELLER, 2006). To illustrate the influence of factors in the purchase decision process, Kotler (2006) categorizes them in important function:

Board 1 - Influence Factors in the Process of Purchase Decision

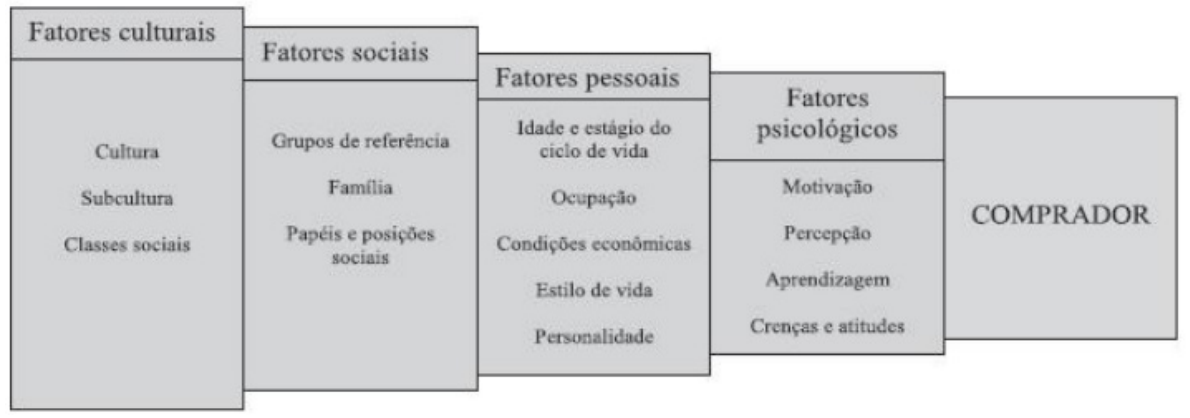

Source: adapted from Kotler (2006).

The following section outlines the procedures to bring forward the objective of this research.

\section{METHODS}

This study will be descriptive, replicating the method used in another context, and intends to confront the findings with previous study. ${ }^{6}$ It is, therefore, a repeated study, with consent of the pioneering researchers, and has confirmatory character, the descriptive level and cross-sectional. At this level, according to Gil (1987, p. 45), the studies "[...] has as its primary objective the description of the characteristics of certain people or phenomena or establishing relationships between variables.” Data were collected between September 2013 and January 2014, featuring the cross-sectional study, according to Hoppen, Lapoint and Moreau (1996).

To achieve the objectives of the study were combined different methods. We used the comparative method to the observational reconciled and statistical methods. According to the literature the characteristics of these methods justify their delimitation for this study. The comparative method "[...] proceeds by research subjects, classes, phenomena or events in order to highlight the differences and similarities between them.” (GIL, 1987, p. 35). Circumstances highlighted the differences in behavior between the variables studied. Gil (1978, p. 34), “[...] can be said with confidence that 
any social science research should consider, in more than a moment of observational procedures." Situation which supports the results of this research on the results of other studies, even when opposed relationships between variables. And finally the statistical method "[...] is based on the application of statistical probability theory and an important aid for research in social sciences [...] and provide considerable strengthening the conclusions.” (GIL, 1987, p. 36). Used to support the responses obtained in the survey. It is in this case a quantitative character study.

The research universe consists of families from the city of Chapecó, SC. The sample was determined by convenience (stratified in terms of Marconi and Lakastos 1999, p. 59), the stratification criterion the age of the respondent, assuming that this variable select individuals with purchasing decisions and indicating different behaviors, habits and training among respondents. ${ }^{7}$ Gil (1987, p. 95) “[... there are situations where this procedure is the most widely adopted, particularly those in which it has an interest in comparing various strata.” The sample size resulted in 300 families, noting that there were some interviews eliminated by not finding the respondent and criteria of lack of consistency, ${ }^{8}$ and research has a confidence level of $95 \%$, with a sampling error of $5 \%$.

As data collection instrument was used in survey research that " [...] involves the examination of the phenomenon in a wide variety of natural environments" (PINSONNEAULT; KRAEMER, 1993, p. 5), the data captured through interview structured. The instrument making came from a broad review of the literature ${ }^{9}$ to generate the statements, and was used a form similar to that used in pioneering research. After the form has been submitted to a pre-test when they were interviewed 10 people with age and different degree of education in order to check the understanding of the issues. Adjusted the form, beginning occurred interviews.

The interviews were conducted in the same way with all interviewed because, according to HAIR JÚNIOR Junior et al. (2006, p. 163) "For each interview, the interviewer should use the same sequence and conduct the interview exactly the same way to avoid bias that may result from inconsistent practices.” In this study, all interviews were conducted by the same person.

For tabulation and analysis of data and interpretation of the results, we used the computer resources of the software Sphinx ${ }^{\circledR}$ and Excel ${ }^{\circledR}$. In order to achieve the research objectives, a number of measures, techniques and statistical tests were performed. The first step of the analysis itself was generating a monosserial analysis (frequency distribution) of the responses to each question asked. Measure of central tendency to be used (average), especially in the Scalar issues. The arithmetic mean 
associated with the scale is indicated as "[...] if you want to get an average of central tendency that has the highest stability.” (GIL, 1987, p. 175). Frequency distribution, maximum and minimum values, variable intersections, nonparametric tests (such as chi-square) were the resources to which they resorted to support to describe, analyze and interpret the survey data.

In the section that follows, at first present some findings of this research, and compare the same with the results of pioneering research.

\section{DATA ANALYSIS}

This section presents a brief analysis of the results obtained during the research, segmenting the points of influence in consumption depending on the age of the respondent, stratified by generation.

\subsection{INFLUENCE FACTORS IN COLONIAL PRODUCTS CONSUMPTION}

Respondents were asked about the importance of colonial appeal in purchasing decisions of colonial products and the results show that it is important for most, as can be seen in Table 1.

Table 1 - Colonial Appeal

\begin{tabular}{lllll}
\hline & Without importance & Low importance & Important & High importance \\
\hline Remember of childhood & 66 & 67 & 124 & 43 \\
Are healthy & 21 & 42 & 184 & 53 \\
\hline Are ecological correct & 69 & 78 & 122 & 31 \\
\hline Tastier & 18 & 37 & 170 & 75 \\
Family tradition & 43 & 67 & 159 & 31 \\
Know the manufacturer & 37 & 47 & 155 & 61 \\
\hline
\end{tabular}

Source: the authors.

When grouped the important and very important answers that have most relevant appeals are tastier (81.7), are healthy (79\%) know the manufacturer (72\%) and tradition (63.3\%).

In the buying decision of the respondents the factors that most influences (considering the degrees of importance as Important and Very Important), in descending order were: Validity (98.3\%), taste (96.3\%), appearance (94, 7\%) and ingredients (93.6\%). Also the two factors that influence the decision not to buy were Overdue product (90\%) and Price High (61.3\%). 
Regarding the preference for Colonial or Industrialized products, 61.3\% prefer the colonial, and when this information related to the age of the respondent, it is noted that the percentage of preference for colonial product increases progressively in relation to increasing age. Pertinently all respondents with more than 70 years cite prefer colonial products (see Table 2).

Table 2 - Preference for products relating to age

\begin{tabular}{llll}
\hline PREFERENCE AGE & Industrialized (\%) & Colonial (\%) & Indifferent (\%) \\
\hline Less than 20 & 12,5 & 37,5 & 50 \\
From 20 to 30 & 27,5 & 47,1 & 25,5 \\
From 30 to 40 & 16,5 & 56,3 & 27,6 \\
From 40 to 50 & 10,5 & 52,6 & 36,8 \\
From 50 to 60 & 10,2 & 71,4 & 18,4 \\
From 60 to 70 & 2,9 & 85,3 & 11,8 \\
More than 70 & 0,0 & 100 & 0,0 \\
\hline TOTAL & 13,7 & 61,3 & 25 \\
\hline
\end{tabular}

Source: the authors.

This result shows the fact of having different consumer trends between generations, according to Rocha-de-Oliveira, Piccinini and Bitencourt (2011), Generation Y (born from 1980), has distinct characteristics from the generation born before 1979, that influence of being and acting in society, and it is this set of behaviors and values that differentiate the consumption of these generations. Table 3 shows the preference of respondents, when stratified by generation $\mathrm{Y}$ and others.

Table 3 - Relation of consumer preferences X generation

\begin{tabular}{lll}
\hline AGE PREFERENCE & Less than 35 (Generation Y)(\%) & More than 35 (\%) \\
Industrialized & 58,5 & 41,5 \\
Colonial & 27,7 & 72,3 \\
Indifferent & 44 & 56 \\
\hline
\end{tabular}

Source: the authors.

Table 3 illustrates the differences between generations, and based it is noted that the generation of people over 35 years has a considerable difference in preference to colonial products compared to Generation Y. According to Quevedo-Silva, Lima Filho and Fagundes (2012 p. 3), the buying decision process is related "[...] the changes occurring in society in the twentieth century, leading people to a new 
lifestyle and, consequently, the new eating habits.” (QUEVEDO-SILVA; LIMA SON; FAGUNDES, 2012, p. 2).

In this context, Table 4 shows the differences between generations as the frequency of consumption, it must be considered that although there is a preference for a particular product does not always mean not consume the least preferred, since the region is traditionally agricultural ${ }^{10}$ and the influence of consumer tradition ${ }^{11}$ of colonial products should be considered.

Table 4 - Consumption of colonial products in relation to age

\begin{tabular}{lllll}
\hline OFTEN AGE & Rarely (\%) & Occasionally (\%) & Often (\%) & High (\%) Often (\%) \\
\hline Less than 35 years & 13 & 42,6 & 38,9 & 4,6 \\
More than 35 years & 10,4 & 29,2 & 50 & 10,4 \\
\hline
\end{tabular}

Source: the authors.

Another point about the price of colonial products is that people were asked to inform thought they were paying more, cheaper or the same value for colonial products compared to the same manufactured products. The results show that as the wages increased, people tended to judge more expensive the amount paid for colonial. Of families with monthly income below R\$3,000.00 (50.5\%) believe pay cheaper or the same value. In the group of families with monthly income of $\mathrm{R} \$ 3,000.00$ to $\mathrm{R} \$$ 6,000.00 (36.9\%) reported paying more for the colonial products. When income increases to the range of $R \$ 9,000.00$ to $R \$ 12,000.00$, the percentage of those who think paying more is $63.6 \%$.

These results are related to the consumption habits of each income range, that is, families with lower incomes tend to select the consumer item according to the value and end up consuming more simple products without many variations. But when income levels increase, the range of products also increases, so when think they are paying more for the same industrial product, are compared to their habit of consumption and the amount of consumed products. It should be noted that in most cases, the comparisons made by households (in different income levels) are quite different from each other.

The findings of this study, it is possible to conclude that there is a higher consumption in the study region, colonial products, when compared to industrialized, however, observed that the decision to purchase and consumption of these products is influenced by several factors (as explained previously). Another of them, cited by many respondents, is the high value of some specific colonial products, which end up leaving the consumer role of families and/or replaced. 
The following subsection counteracts the results of this research with the pioneer one, with regard in colonial appeal.

\subsection{COMPARATIVE RESULTS OF COLONIAL APPEAL WITH PREVIOUS STUDY}

Because of the confirmatory nature of this study, we compared the data obtained in this study, for the colonial appeal with the data obtained in a previous study, with consent of the pioneering researchers in order to sustain the results of the previous study in different context.

As the colonial appeal is relevant to this work, the cumulative results of the importance of the appeal (important and very important), and are considered as colonial appeal the factors resemble childhood, ${ }^{12}$ are tastier, are healthier, ${ }^{13}$ they are environmentally friendly ${ }^{14}$ it is family tradition ${ }^{15}$ and know the producer, ${ }^{16}$ following described in Table 5:

Table 5 - Comparison of appeals pointed out in previous research and current

\begin{tabular}{lll}
\hline & Previous Study (\%) & Actual Study (\%) \\
\hline Remember of childhood & 74,60 & 55,67 \\
Are healthy & 94,80 & 79,00 \\
Are ecological correct & 74,80 & 51,00 \\
Tastier & 91,30 & 81,67 \\
Family tradition & 80,00 & 63,33 \\
Know the manufacturer & 88,30 & 72,00 \\
\hline
\end{tabular}

Source: the authors.

Note: The brown marked cells are those in which the actual frequency is clearly higher (lower) than the theoretical frequency.

As noted in Table 5, the contents with greater appeal following the previous study of the trend, although there was a decline in the percentage, the calls: are healthier and are more flavorful, were considered most important in the buying decision, with 79, $00 \%$ for this study are healthier, against $94.80 \%$ in the previous study. As they are tastier with $81.67 \%$ in this study, compared with $91.30 \%$ in the previous study.

\section{CONCLUSION}

From this study we can infer that consumers in general, attach special interest to these products, and give them values not perceived in the products of conventional 
industries. The findings show that for most respondents is important that colonial products are produced in a traditional manner, preserving the know-how of the producer. That is, differently from the process used in large industry.

This confirmation indicates that legal measures should be adjusted not to induce the mischaracterization the differentiating factor of colonial products, whether public policies effectively want the stimulus and the survival of small RAs.

To note that there are significant relationship between the age of the respondent in relation to consumption of colonial products, confirming the findings of the first study. The importance of the attributes from colonial product is smaller considered the importance for young people, offering evidence that in the long term, there may be reduction of consumption of colonial products. This result indicates that marketing strategies should be encouraged, together with the RAs, to become the most attractive colonial product to young people.

The overall results confirm the previous findings of the study, and meet the objectives of this study, carried out in another context. It is suggested, however, to repeat the study in other Brazilian states and seeking to identify, because the colonial product is losing attractiveness in the younger population.

Explanatory notes:

\footnotetext{
${ }^{1}$ Study financed with funds from the State of Santa Catarina through Art. 170.

${ }^{2}$ Typical product of small farms, done by hand.

${ }^{3}$ The National Program for Strengthening Family Agriculture (Pronaf) is intended to stimulate income generation and improve the use of family labor, through the activities of financing and agricultural rural services and non-agricultural developed in rural establishment or in areas Community next. More details in Banco do Brasil (2015).

${ }^{4}$ In the case of vertical integration of the major industries of the Midwest of Santa Catarina, for integrated, they are at the same time, the monopoly and monopsony.

${ }^{5}$ To see deepening http://www.mda.gov.br/sitemda/secretaria/saf-suasa/sobre-o-programa

${ }^{6}$ View: Santos Junior, Marini and Fischer (2013).

${ }^{7}$ Studies on consumption differentiate the buying decision of the consumer decision. In this study, the questions during the interview, sought to investigate the household consumption of the interviewee, not considering whether it's who has the "responsibility for the family supply shop."

${ }^{8}$ Criteria assessed on the basis of numerous questionnaires without consistency in test responses (assessment of researchers).

${ }^{9}$ Of the literature that formed the questionnaire cannot be outlined here, due to shortage of editorial space.

${ }^{10}$ The production concentration in western Santa Catarina extension is predominantly agricultural and agroindustrial (MIOR, 2005).

${ }^{11}$ See Barbosa and Campbell (2006, p. 39).
} 


\footnotetext{
12 “Tightly linked to socio-cultural relations (the childhood memories, healthy products, among other calls) targets these Rural Agroindustries public attach particular interest to the products manufactured by them [...]” (SANTOS JUNIOR, 2011, p. 18).

${ }^{13}$ Family agribusiness products have little use of external inputs against chemical model of agribusiness (WILKINSON, 2009).

${ }^{14}$ Agricultural production is based on the principles of ecology, it uses few inputs (WILKINSON, 2009). 15 “Steiner (2006), Wilkinson (2008), Renard (2003), Dorigon (2008), among others, show the” call "that makes the culture, tradition, social” (SANTOS JUNIOR, 2011, p. 122) it is one of the distinguishing characteristics for colonial products.

16 “[...] The relationship of proximity influence on customer trust in the producer.” (SANTOS JUNIOR, 2011, p. 101).
}

\section{REFERENCES}

BAIXAR MAPAS. Mapas de Santa Catarina - Mesorregiões. Available from: $<$ http://www.baixarmapas.com.br/mapa-de-santa-catarina-mesorregioes > . Access on: Feb. 32016.

\section{BANCO DO BRASIL. FAQ - Programa Nacional de Fortalecimento da Agri-} cultura Familiar - Pronaf. jul. 2015. Available from: <http://www.bcb.gov.br/pre/ bc_atende/port/PRONAF.asp\#1>. Access on: Feb. 32016.

BARBOSA, L.; CAMPBELL, C. O estudo do consumo nas ciências sociais contemporâneas. In: BARBOSA, L.; CAMPBELL, C. (Org.). Cultura, consumo e identidade. Rio de Janeiro: FGV, 2006. p. 21-44.

BAVARESCO, P. Ciclos Econômicos Regionais: modernização e empobrecimento no Extremo Oeste catarinense. Chapecó: Argos, 2005.

BENEDET FILHO, B. Formas de inserção nos mercados utilizados pelos agricultores e agroindústrias familiares da Região Sul do Estado de Santa Catarina. 2004. 174 p. Dissertação (Mestrado em Agronegócios)-Universidade Federal do Rio Grande do Sul, Porto Alegre, 2004.

\section{BANCO NACIONAL DO DESENVOLVIMENTO. Arranjos Produtivos Locais} e Desenvolvimento. 2004. Available from: <www.bndes.org.br>. Access on: Feb. 3 2005.

COBRA, M. Administração de marketing no Brasil. São Paulo: Cobra Editora de Marketing, 2003. 
DORIGON, C. Mercados de Produtos Coloniais da Região Oeste de Santa Catarina: em Construção. 2008. 437 p. Tese (Doutorado em Engenharia da Produção)Universidade Federal do Rio de Janeiro, Rio de Janeiro, 2008.

FIGUEIREDO, A. S. (Org.). Conhecendo seu canal de comercialização de hortaliças. Universidade Católica de Brasília. Empresa de Assistência Técnica e Extensão Rural e Conselho Nacional de Desenvolvimento Científico e Tecnológico. Brasília, DF: Emater, 2003.

GIL, A. C. Métodos e técnicas de pesquisa social. São Paulo: Atlas, 1987.

GREMAUD, A. P.; VASCONCELOS, M. A. S.; JÚNIOR, R. T. Economia Brasileira Contemporânea. 6. ed. 3. reimpr. São Paulo: Atlas 2007.

GUimarÃes, G. M.; SILVEIRA, P. R. C. da. Por trás da falsa homogeneidade do termo agroindústria familiar rural: indefinição conceitual e incoerências das políticas públicas. Available from: <http://www.cnpat.embrapa.br/sbsp/anais/Trab_ Format_PDF/99.pdf>. Access on: Feb. 102012.

GUIMARÃES, G. M. A Legislação Industrial e Sanitária dos Produtos de Origem Animal - O Caso das Agroindústrias de Pequeno Porte. 2001. Dissertação (Mestrado em Extensão Rural)-Programa de Pós-Graduação em Extensão Rural, Universidade Federal de Santa Maria, Santa Maria, 2001.

HAIR JÚNIOR, F. J. et al. Fundamentos de métodos de pesquisa em administração. Porto Alegre: Bookman, 2006.

HAIR JÚNIOR, F. J. et al. Análise multivariada de dados. 6. ed. Porto Alegre: Bookman, 2009.

HOPPEN, N.; LAPOINT, L.; MOREAU, E. Um guia para avaliação de artigos de pesquisa em sistemas de informação. Revista Eletrônica de Administração, n. 3, ago. 1996.

INSTITUTO CEPA. Instituto de planejamento e economia agrícola de Santa Catarina. Síntese anual da agricultura de Santa Catarina 2000/2001. Florianópolis: 2001. Available from: <http://docweb.epagri.sc.gov.br/website_cepa/publicacoes/ Sintese_2001.pdf>. Access on: Feb. 102016. 
KALNIN, J. L. Desenvolvimento local/regional focado na agroindústria familiar: experiências em Santa Catarina. 2004. 215 p. Tese (Doutorado em Engenharia da Produção)-Universidade Federal de Santa Catarina, Florianópolis, 2004.

KIYOTA, N. Agricultura Familiar e suas estratégias de comercialização um estudo de caso no município de Capanema - Região Sudoeste do Paraná. 1999. Dissertação (Mestrado em Administração Rural)-Universidade Federal de Lavras, Lavras, 1999.

KOTLER, P.; KELLER, K. L. Administração de Marketing. 12. ed. São Paulo: Pearson Prentice Hall, 2006.

MARCONI, M. A.; LAKATOS, E. M. Técnicas de pesquisa: planejamento e execução de pesquisas, amostragens e técnicas de pesquisa, elaboração, análise e interpretação de dados. 4. ed. São Paulo: Atlas, 1999.

MEDEIROS, J. X.; WILKINSON, J.; LIMA, D. M. A. O desenvolvimento científico-tecnológico e a Agricultura Familiar. In: LIMA, D. M. A.; WILKINSON, J. (Org.). Inovações nas tradições da Agricultura Familiar. Brasília: CNPq/Paralelo 15, 2002. p. 23-38.

MINISTÉRIO DO DESENVOLVIMENTO AGRÁRIO, MINISTÉRIO DA AGRICULTURA, PECUÁRIA E ABASTECIMENTO. Seminários Nacionais sobre Sistemas de Inspeção de produtos de origem animal. Available from: <http://seminariossuasa.com.br/index.html\#concurso>. Access on: Mar 192014.

MIOR, L. C. Agricultores familiares, Agroindústrias e território: A dinâmica das redes de desenvolvimento rural no Oeste Catarinense. 2003. 316 p. Tese (Doutorado Interdisciplinar em Ciências Humanas)-Universidade Federal de Santa Catarina, Florianópolis, 2003.

PEREIRA, M. C. S.; NEVES, R. I. S.; CASAROTTO FILHO, N. Redes de agroindústria de pequeno porte: experiências de Santa Catarina. Florianópolis: BRDE, 2004.

PINSONNEAULT, A.; KRAEMER, K. L. Survey research methodology in management information system: an assessment. Journal of Management Information Systems, v. 10, i. 2, p. 75-105, Autumn 1993. 
PREZOTTO, L. L. Agroindústria Rural de Pequeno Porte e seu ambiente institucional relativo à legislação sanitária. Florianópolis: UFSC, 1999. Dissertação (Mestrado em Agroecossistemas)-Universidade Federal de Santa Catarina, 1999.

QUEVEDO-SILVA, F.; LIMA FILHO, D. O.; FAGUNDES, M. B. B. Processo de Escolha de Alimentos de Consumidores Idosos. In: ENCONTRO DA ANPAD, 32., 2012, Rio de Janeiro. Anais... Rio de Janeiro, jan. 2012.

REINACH, S.; CORÁ, M. A. J.; BONDUKI, M. R. P. D. A Inclusão da Agricultura Familiar no Programa Nacional de Alimentação Escolar. In: ENCONTRO DA ANPAD, 32., 2012, Rio de Janeiro. Anais... Rio de Janeiro, jan. 2012.

ROCHA-DE-OLIVEIRA, S.; PICCININI, V. C.; BITENCOURT, B. M. Juventudes, gerações e trabalho: é possível falar em geração Y no Brasil? Organizações \& Sociedade, Salvador, v. 19, n. 62, jul./set. 2012.

RENARD, M.-C. Fair trade: quality, market and conventions. Journal of Rural Studies, Hoboken, i. 19, p. 87-96, 2003.

SANTA CATARINA. Secretaria de Estado da Fazenda. Perfil Econômico, Financeiro e Social: Boletim informativo, 2011. Available from: <http://www.sef.sc.gov. br/sites/default/files/Boletim\%20Ano\%2011\%20FINAL_0.pdf>. Access on: Aug. 15 2013.

SANTOS JUNIOR, J.; MARINI, D.; FISCHER, A. The future of colonial products: the influence of age on consumer preference. IDEAS magazine, v. 7, p. 214-238, 2013.

\section{SANTOS JÚNIOR, S. Agroindústria familiar rural no Alto Uruguai do rio}

Grande do Sul: uma análise do processo de comercialização. 2006, 130 p. Dissertação (Mestrado em Agroecossistemas)-Universidade Federal de Santa Catarina, Florianópolis, 2006.

SANTOS JUNIOR, S. A influência dos fatores econômicos, institucionais e sociais na inserção das agroindústrias rurais no mercado: um estudo no Meio-Oeste de Santa Catarina. 2011. 211 p. Tese (Doutorado em Agronegócio)-Universidade Federal do Rio Grande do Sul, Porto Alegre, 2011.

SANTOS JUNIOR, S.; WAQUIL, P. D. A Influência de Fatores Econômicos, Institucionais e Sociais na Inserção de Agroindústrias Rurais em Santa Catarina. Revista de Economia e Sociologia Rural, v. 50, n. 2, p. 263-284, 2012. 
SILVEIRA, P. R. C. da; ZIMERMANN, S. A Qualidade em Circuitos Regionais de Produção de Alimentos numa Perspectiva de Segurança Alimentar. In: FROELICH, M.; DIESEL, V. Espaço Rural e Desenvolvimento Regional. Ijuí: Unijuí, 2004.

TESTA, V. M. et al. O desenvolvimento sustentável do oeste catarinense: proposta para a discussão. Florianópolis: Epagri, 1996.

WELLS, W. R. F. Consumer behavior. New York: McGraw-Hill, 1978.

WIKIPÉDIA. A enciclopédia livre. Anexo: Lista de mesorregiões de Santa Catarina. Available from: <http://pt.wikipedia.org/wiki/Anexo:Lista_de_mesorregi\%C3\%B5es_de_Santa_Catarina>. Access on: Aug. 152013.

WILKINSON, J. A pequena produção e sua relação com os sistemas de distribuição. In: SEMINÁRIO SOBRE POLÍTICAS DE SEGURIDAD ALIMENTARIA Y NUTRICIÓN EN AMÉRICA LATINA, 2003, Campinas. Anais... Campinas, 30 out. 2003.

WILKINSON, J.; MIOR, L. C. Setor informal, produção familiar e pequena agroindústria: interfaces. Estudos Sociedade e Agricultura, n. 13, p. 29-45, 1999.

WILKINSON, J. Mercados, redes e valores: o novo mundo da agricultura familiar. Porto Alegre: UFRGS, 2008.

How to mention this paper:

ABNT:

SCHAEFER, Larissa; SANTOS JUNIOR, Silvio. The market prospects of colonial products. RACE, Revista de Administração, Contabilidade e Economia, Joaçaba: Ed. Unoesc, v. 15, n. 2, p. 729-750 , maio/ago. 2016. Available from: <http://editora. unoesc.edu.br/index.php/race>. Access on: month/day/year.

APA:

Schaefer, L., \& Santos, S. (2016). The market prospects of colonial products. RACE, Revista de Administração, Contabilidade e Economia, 15(2), 729-750. Retrieved from http://editora.unoesc.edu.br/index.php/race 
